Published by Terrier, L., Kim, S., Fernandez, S. in Journal of environmental psychology, 2016, vol. 48, pp. 185-190 which should be cited to refer to this work.

\title{
Who are the good citizens for the environment? An examination of the predictive validity of personality traits
}

\section{Introduction}

In response to the growing interest in climate-related and ecological issues, environmental performance has become an important aspect of organizational performance (Boiral, Paillé \& Raineri, 2015). To address these environmental concerns, an increasing number of organizations promote pro-environmental behaviors and encourage employees to act respectfully vis-à-vis the environment, which often involves individuals carrying out discretionary actions also known as organizational citizenship behaviors for the environment (OCBE; Boiral, 2009).

OCBE can be defined as "individual and discretionary social behaviors that are not explicitly recognized by the formal reward system and that contribute to a more effective environmental management by organizations"' (Boiral, 2009, p.223). This definition highlights the pro-social value of these behaviors, as well as their voluntary dimension, but also provides a closer look into Organizational Citizenship Behaviors (OCB; Organ, Podsakoff \& MacKenzie, 2006) which correspond to individuals’ discrete positive actions in organizations (Lavelle, 2010). The main difference between the two concepts is that OBCEs are applied specifically to the environment. On this basis, Boiral (2009) proposes to define different forms of OCBE by applying the OCBs' classification (Organ et al., 2006) while adding the environmental dimension: helping (collaboration and encouraging other workers to consider environmental issues); sportsmanship (positive attitude toward the inconveniences associated with environmental practices); organizational loyalty (supporting the organization's environmental policies and actions); organizational compliance (compliance with environmental practices and procedures); individual initiative (discretionary suggestions and initiatives in the workplace) and self-development (acquisition of environmental knowledge). 
Nevertheless, according to Lamm, Tosti-Kharas and Williams (2013), this type of taxonomy is quite broad, and research needs to focus on more specific eco-initiatives such as recycling bottles, using scrap paper for notes, printing double-sided, turning off lights when leaving the office, etc. To address these concerns, Boiral and Paillé (2012) conducted an analysis to create an appropriate measurement and definition of OCBE comprised of three dimensions:

1/ Eco-initiatives relates to personal initiatives in the workplace such as making suggestions to conserve energy, voluntary initiatives to reduce water consumption, etc. This first dimension is behavioral and, by definition, action-oriented.

2/ Eco-civic engagement relates to voluntary involvement in the organization's environmental programs such as becoming a member of an environmental committee or participating in environmental events organized by the company. These behaviors are linked both to environmental and organizational loyalty (Boiral \& Paillé, 2012). This second dimension is more strategic and can provide support for eco-initiatives and, more generally, organization-level green initiatives.

3/ Eco-helping relates to motivation to encourage and help colleagues to take into account environmental concerns. This dimension can involve promoting ecological behaviors with new employees and it is collaborative in nature.

This tri-dimensional definition presents the advantage of assessing different aspects of OCBE. Indeed, while research has investigated the eco-initiative aspect of OCBE (Andersson \& Bateman 2000; Hanna et al., 2000; Ramus 2001; Ramus \& Steger, 2000), eco-engagement and eco-helping dimensions have been often overlooked (Boiral \& Paillé, 2012).

These behaviors represent nearly $70 \%$ of the ecological behaviors performed at work (Boiral et al., 2015) and are positively associated with the environmental performance of an organization (Ramus \& Killmer 2007). For instance, the results of several research papers show that employees' green commitment and behavior can be linked to pollution reduction and prevention or better waste management (Theyel, 2000; Borial 2005). In particular, managers 
with high OCBE improve the environmental performance of their team's work significantly (Boiral, Talbot \& Paillé, 2015). Finally, a number of green organizations (3M, Patagonia, etc.) have explicitly linked their success to employees’ eco-behaviors (Borail \& Paillé, 2012).

While research has shed light on the effects of OCBE, there is a need for understanding the antecedents of OCBE. Hence, the purpose of this paper is to study the effects of the five factor model (FFM also known as the Big five) on OCBE.

1.1. Personality and positive discretionary behaviors

Research on personality traits feature heavily in the organizational behavior literature and have shown that personality traits can predict a large variety of behaviors (McCrae \& Costa, 2008; Roccas, Sagiv, Schwartz, \& Knafo, 2002).

Based on the five factor model, differences between individuals in terms of personality can be captured through five main traits, including each of the following six facets (McCrae \& Costa, 1997):

- Openness to experience relates to the fact of appreciating divergent thinking, new social, ethical and political ideas, behaviors and values (facets: Openness to fantasy, aesthetics, feelings, actions, ideas and values). Individuals Open to Experience are curious, imaginative and unconventional. Openness to experience is linked to success in adaption to change (Rothman \& Coetzer, 2003).

- Conscientiousness is associated with self-discipline, competence, dutifulness and responsibility (facets: Competence, order, dutifulness, achievement striving, selfdiscipline and deliberation). Conscientious individuals are rational, purposeful, strongwilled, like to follow rules and have clear objectives. Conscientiousness is significantly linked to performance (Barrick \& Mount, 1991; Ones \& Viswesvaran, 1997; Sackett \& Wannek, 1996).

- Extraversion refers to the tendency to be energized by social interactions, excitement and diverse activities (facets: Warmth, gregariousness, assertiveness, activity, 
excitement-seeking and positive emotions). Extraverted individuals are talkative, assertive and optimist. Extraversion is a valid predictor of performance in jobs characterized by social interactions (Barrick \& Mount, 1991; Bing \& Lounsbury, 2000).

- Agreeableness is characterized by altruism, modesty, straightforwardness and a cooperative nature. Agreeable individuals are sympathetic to others and tolerant (facets: Trust, straightforwardness, altruism, compliance, modesty and tender-mindedness). According to Rothman and Coetzer (2003), the co-operative nature of agreeable individuals may lead to success in jobs involving collaboration and service (Judge, Higgins, Thoresen \& Barrick, 1999).

- Neuroticism relates to the tendency to experience negative emotions such as fear and sadness. Individuals with high neuroticism levels are impulsive, stressful and badtempered (facets: Anxiety, angry/hostility, depression, self-consciousness, impulsiveness and vulnerability). Neuroticism is mainly inversely related to job performance (Judge et al., 1999).

The five factor model has proven reliable in predicting performance at work (Barrick, Parks \& Mount, 2005; Barrick, Mount \& Judge, 2001). For instance, Mount and Barrick (1995) show that conscientious individuals show high autonomy levels at work, and, by consequence, perform well. Personality can also have an impact on voluntary extra-role behaviors performed by employees. Analysis of these voluntary behaviors is important because they can have a major impact on organizational performance (MacKenzie, Podsakoff \& Fetter, 1993).

Likewise, research has investigated the link between the big five and organizational citizenship behaviors (OCB; Organ, Podsakoff \& MacKenzie, 2006) which correspond to individuals' discrete positive actions in organizations (Lavelle, 2010). OCBE and OCB are distinct yet related constructs (Paillé \& Boiral, 2013). OCB are spontaneous, not linked to job requirements, and have an impact on work effectiveness (Chiaburu, Oh, Berry, Li, \& Gardner, 2011). Although all five traits have an impact on OCBs, conscientiousness and agreeableness 
are the most significant predictors of OCB (Hurtz \& Donovan, 2000; Organ \& Ryan, 1995). Indeed, conscientious individuals are more trustworthy, self-disciplined and responsible. These attributes are linked to citizenship, pro-activity and performance and, consequently, to OCBs (Ilies, Fulmer, Spitzmuller \& Johnson, 2009; Organ \& Ryan, 1995; Organ et al., 2006). Agreeable people tend to be more altruistic and are more eager to help others. Thus, they are predisposed to be engaged in supportive actions, such as OCB (Ilies et al., 2009). As OCBE and OCB are distinct yet related constructs (Boiral, 2009), we expect agreeableness and conscientiousness to be related to OCBE.

Hypothesis 1. Agreeableness and conscientiousness will positively relate to OCBE.

\subsection{Personality and environmental concerns}

According to the different theoretical models proposed, OCBE are driven by organizational and personal factors (Daily, Bishop \& Govindarajulu, 2009; Lülfs \& Hahn, 2013; Ramus \& Killmer, 2007). We assume that personality traits could be considered to be one of the personal factors explaining why some workers perform green behaviors voluntarily. Indeed, although only a few research have tested the link between personality and pro-environmental behaviors, the results demonstrate that personality traits can predict environmental concern (Brick \& Lewis, 2014), specifically openness to experience and extraversion. The alternative thinking component of openness to experience helps individuals to question themselves about their level of environmental concern and how new behaviors can impact their environment (Hilbig, Zettler, Moshagen, \& Heydasch, 2012; Markowitz, Goldberg, Ashton, \& Lee, 2012). Furthermore, openness is also characterized by a flexible way of thinking that can foster the development of a long-term vision regarding the consequences of climate change (Brick \& Lewis, 2014). This is probably why openness seems linked to environmental concern (Brick \& Lewis, 2014; Hilbig et al., 2012; Hirsh \& Dolderman, 2007; Markowitz et al., 2012). Researchers have also shown that extraversion can predict environmental behavior (Hilbig et al., 2012; Hirsh \& Dolderman, 2007), which can be explained by the fact that establishing a new environmental behavior can 
sometimes be difficult as individuals are confronted with pre-existing organizational norms and rules. They must be assertive in order to implement these new behaviors. Thus, we hypothesize that openness to experience and extraversion will provide incremental validity to explain OCBE above and beyond agreeableness and conscientiousness. Hypothesis 2. Openness to experience and extraversion will provide incremental validity to predict OCBE above and beyond agreeableness and conscientiousness.

\section{Method}

\subsection{Sample and Procedure}

The sample used in the present study consisted of students at a hospitality management school located in Switzerland. In 2013, 290 students completed a personality questionnaire as part of a class assignment in an Organizational Behavior course. Two years later, in 2015, the same students were asked to complete the OCBE survey on their return from a six-month internship. In total, our study includes 178 participants who completed both surveys at different points of time (mean age: $22.62(S D=1.59) ; 61.8 \%$ of the respondents are females). There is then a retention rate of $61.4 \%$. Drop-outs are mainly students who have failed or interrupted their studies.

\subsection{Measures}

Big five personality factors. To measure the big five and its 30 facets, we used the 300 -item International Personality Item Pool (IPIP-300) developed by Goldberg (1999). Participants used a 5-point scale ranging from 1 (very inaccurate) to 5 (very accurate) to respond to the items. Past research has shown that this instrument possesses adequate psychometric characteristics (Goldberg, 1999; Goldberg et al., 2006). Reliabilities for the five traits range from .87 to .95 and for the facets from .59 to .90 .

Organizational citizenship behaviors for the environment (OCBE). To measure OCBE, we used an adaptation of the 10-item OCBE scale developed by Boiral and Paillé (2012). The ecoinitiatives factor was measured through 3 items (e.g., "During my internship, I have weighed 
the consequences of my actions before doing something that could affect the environment”); Eco-civic engagement included 4 items (e.g., "During my internship, I have actively participated in environmental events organized in and/or by my organization”); and Ecohelping included 3 items (e.g., "During my internship, I encouraged my colleagues to adopt more environmentally conscious behavior”). Participants used a 5-point scale ranging from 1 (completely disagree) to 5 (completely agree) to respond to the items. Reliability for the three dimensions of OCBE ranges from .70 to .85 .

\section{Results}

Insert Table 1 and Table 2

Table 1 presents the descriptive statistics (means and standard deviations), reliabilities and correlations of the main variables used in this study. All factors, with the exception of agreeableness, correlated with OCBE. Eco-initiatives also correlated significantly with four out of the big five dimensions. Eco-civic engagements correlated positively and significantly with conscientiousness, extraversion and agreeableness. Eco-helping correlated positively and significantly with extraversion and openness. Table 2 shows correlations between personality facets and OCBE. Three facets of openness (namely aesthetics, actions and ideas), three facets of conscientiousness (competence, achievement striving and self-discipline), one facet of extraversion (warmth) and two facets of agreeableness (trust and altruism) are correlated positively to OCBE. However, none of the facets related to neuroticism are linked to OCBE (as well as with the three OCBE factors). When looking at specific factors of OCBE, six facets are correlated to eco-initiatives, three facets are correlated with eco-civic engagement and seven facets are correlated with eco-helping. Table 3 displays the results of the hierarchical regressions used to test the hypotheses. 
Insert Table 3

Hypothesis 1 and 2 were tested with hierarchical regression analyses. First, age and gender were entered in the first step of the regression to predict OCBE. Second, conscientiousness and agreeableness were entered in a second step. These variables were entered early in the model because previous research has already shown that they predict OCB. It is hypothesized that they should predict as well as OCBE. Finally, openness and extraversion were entered in the third step. As shown in Table 3, conscientiousness and agreeableness accounted for an additional and significant amount of variance over and above gender and age. The same occurred for extraversion and openness which accounted for a significant amount of variance in OCBE over and above the other variables entered in the regression.

When looking at specific factors of OCBE, conscientiousness and agreeableness accounted for an additional and significant amount of variance over and above gender and age to predict eco-initiatives, and openness to experience and extraversion accounted for a larger and significant amount of variance to predict eco-initiatives. Conscientiousness and agreeableness also accounted for an additional and significant amount of variance over and above gender and age to predict eco-civic engagement, and openness to experience and extraversion accounted for a larger and significant amount of variance in the third step of the hierarchical regression analysis. In order to predict eco-helping, conscientiousness and agreeableness did not account for an additional and significant amount of variance over and above gender and age. However, openness to experience and extraversion accounted for a larger and significant amount of variance over and above age, gender, agreeableness and conscientiousness.

\section{Discussion}

While consequences of OCBE have been well documented (Boiral, 2005; Boiral et al., 2015; Ramus \& Killmer, 2007; Theyel, 2000) their antecedents have often been overlooked. 
The purpose of this paper was to study the effects of the five factor model on OCBE. As we expected, results show that OCBE can be predicted by personality traits. Indeed, Agreeableness, Conscientiousness, Openness and extraversion are linked to OCBE. These results show that personality can be a valid predictor of voluntary green behavior in organizations.

In addition to these results, we conducted a more in-depth analysis by examining personality traits and the three OCBE dimensions. Our results show that openness to experience is linked to eco-helping. This might be explained by the fact that open-minded individuals are driven by unconventional ways of thinking and, by consequence, seek to influence others to find and adopt alternative solutions with regard to the environment. Indeed, openness is associated with individuals' pro-activity and motivation to get ahead (Hogan \& Holland, 2003). Nevertheless, contrary to our expectations, agreeableness did not predict any of the OCBE dimensions. While this result is surprising, this might also imply that good-natured and cooperative individuals invest with others' perspectives and might be less concerned about environmental issues. Furthermore, the effects of agreeableness on environmental concerns have been inconsistent as some research found a positive relationship (Hirsh \& Dolderman, 2007; Hirsh, 2010) while others have demonstrated the effect to be modest (Markowitz et al., 2012; Milfont \& Sibley, 2012). Furthermore, Brick and Lewis (2014) - using HEXACO - did not find a relationship between agreeableness and environmental behavior.

Results also show that conscientiousness relates positively to eco-initiatives. The active dimension of eco-initiatives could explain these results. Indeed, since they are trustworthy, selfdisciplined and performance-seeking, conscientious individuals are characterized by a “functional personality” (Mount, Barrick, \& Ryan, 2003; Ones, Viswesvaran, \& Schmidt, 1993) and are willing to personally carry out initiatives to protect the environment (i.e. eco-initiative). Finally, extraversion predicted eco-civic engagement. It suggests that action-driven people who enjoy the company of others prefer to engage in environmental programs and activities. Indeed, 
extroverted people are gregarious and energized by group activities such as those linked to ecocivic engagement.

Overall, our results shows that personality is associated with OCBE. More precisely, as predicted by OCB and environmental concerns, agreeableness, conscientiousness, openness to experience and extraversion predict OCBE scores and specific OCBE dimensions.

From a practical point of view, it is important to understand the antecedents of OCBE. Indeed, OCBE are linked to environmental and organizational performance (Boiral et al., 2015). Furthermore, personality aspects should be considered in recruiting, identifying, and selecting employees and managers in order to use OCBE as a personal skill to enhance performance. As reflected in the standards for ISO 14001 certification, a responsible management team can be viewed as a key element for organizations (Boiral, 2005).

This research has two limitations, in particular. The first limitation is that both measures are self-reports. While research has shown that self-reports are a relevant method with which to assess behavior, subsequent research should seek to assess these dimensions on a behavioral basis. The second limitation is linked to the limited work experience of the undergraduates as they might not have had the opportunity or time to engage themselves in OCBE. Future research should assess the OCBE of more experienced workers. 


\section{References}

Andersson, L., \& Bateman, T. (2000). Individual environmental initiative: Championing natural environmental issues in U.S. Business Organizations. Academy of Management Journal, 43(4), 548-570. doi: 10.2307/1556355.

Barrick, M.R., \& Mount, M.K. (1991). The big five personality dimensions and job performance: A meta-analysis. Personnel Psychology, 44, 1-26. doi: 10.1111/j.17446570.1991.tb00688.x.

Barrick, M. R., Mount, M. K., \& Judge, T. A. (2001). Personality and performance at the beginning of a new millennium : What do we know and where do we go next ? International Journal of Selection and Assessment, 9, 9-30.

Barrick, M. R., Parks, L., \& Mount, M. K. (2005). Self-monitoring as a moderator of the relationships between personality traits and performance, Personnel Psychology, 58(3), 745767.

Bing, M.N. \& Lounsbury, J.W. (2000). Openness and job performance in U.S.-based Japanese manufacturing companies. Journal of Business and Psychology, 14, 515-522. doi: 10.1023/A:1022940519157.

Boiral, O. (2005). The impact of operator involvement in pollution reduction: Case studies in Canadian chemical companies. Business Strategy and the Environment, 14, 339-360.

Boiral, O. (2009). Greening the corporation through organizational citizenship behavior. Journal of Business Ethics, 87(2), 221-236. doi:10.1007/s10551-008-9881-2.

Boiral, O., \& Paillé, P. (2012). Organizational citizenship behaviour for the environment: Measurement and validation. Journal of Business Ethics, 109(4), 431-445. doi:10.1007/s10551011-1138-9.

Boiral, O., Talbot, D., \& Paillé, P. (2015). Leading by example: A model of organizational citizenship behavior for the environment. Business Strategy and the Environment, 24(6), 532550. doi:10.1002/bse.1835.

Boiral, O., Pallié, P., \& Raineri, N. (2015). The nature of employees’ pro-environmental behaviors. In Robertson, J. L., \& Barling, J. (Eds.). The psychology of green organizations, The nature of employees' pro-environmental behaviors. Presses universitaires d'Oxford: Oxford.

Brick, C., \& Lewis, G. J. (2014). Unearthing the “Green” Personality Core Traits Predict Environmentally Friendly Behavior. Environment and Behavior, 46(7), 1-24. doi:10.1177/0013916514554695. 
Chiaburu, D. S., Oh, I., Berry, C. M., Li, N., \& Gardner, R. G. (2011). The five-factor model of personality traits and organizational citizenship behaviors: A meta-analysis. Journal of Applied Psychology, 96(6), 1140-1166. doi:org/10.1037/a0024004.

Daily B.F., Bishop J.W., \& Govindarajulu, N. (2009). A conceptual model for organizational citizenship behavior directed toward the environment. Business and Society, 48, 243-256.

Goldberg, L. R. (1999). A broad-bandwidth, public domain, personality inventory measuring the lower-level facets of several five-factor models. Personality psychology in Europe, 7(1), 728.

Goldberg, L. R., Johnson, J. A., Eber, H. W., Hogan, R., Ashton, M. C., Cloninger, C. R., \& Gough, H. G. (2006). The international personality item pool and the future of public-domain personality measures. Journal of Research in personality, 40(1), 8496. doi:10.1016/j.jrp.2005.08.007.

Hanna, M. D., Newman, W. R., \& Johnson, P. (2000). Linking operational and environmental improvement through employee involvement. International Journal of Operations and Production Management, 30(2), 148-165.

Hilbig, B. E., Zettler, I., Moshagen, M., \& Heydasch, T. (2012). Tracing the path from personality - via cooperativeness - to conservation. European Journal of Personality, 27(4), 319-327. doi:10.1002/per.1856.

Hirsh, J. B. (2010). Personality and environmental concern. Journal of Environmental Psychology, 30(2), 245-248. doi:10.1016/j.jenvp.2010.01.004.

Hirsh, J. B., \& Dolderman, D. (2007). Personality predictors of consumerism and environmentalism: A preliminary study. Personality and Individual Differences, 43(6), 15831593. doi:10.1016/j.paid.2007.04.015.

Hogan, J., \& Holland, B. (2003). Using theory to evaluate personality and job-performance relations: A socioanalytic perspective. Journal of Applied Psychology, 88(1), 100-112. Doi: 10.1037/0021-9010.88.1.100

Hurtz, G.M., \& Donovan, J.J. (2000). Personality and job performance: The big five revisited. Journal of Applied Psychology, 85(6), 869-879. doi:org/10.1037/00219010.85.6.869.

Ilies, R., Fulmer, I. S., Spitzmuller, M., \& Johnson, M. D. 2009. Personality and citizenship behavior: The mediating role of job satisfaction. Journal of Applied Psychology, 94: 945-959. 
Judge. T.A., Higgins, C.A., Thoresen, C.J. \& Barrick, M.R. (1999). The big five personality traits, general mental ability, and career success across the life span. Personnel Psychology, 52, 621-652.

Lamm, E., Tosti-Kharas, J., \& Williams, E. (2013). Read this article but don't print it: Organizational Citizenship Behavior toward the Environment. Group \& Organization Management, 38, 163-197.

Lavelle, J. J. (2010). What motivates OCB? Insights from the volunteerism literature. Journal of Organizational Behavior, 31(6), 918-923. doi:10.1002/job.644.

Lülfs R, \& Hahn, R. (2013). Corporate greening beyond formal programs, initiatives, and systems: a conceptual model for voluntary proenvironmental behavior of employees. European Management Review, 10, 83-98.

Markowitz, E. M., Goldberg, L. R., Ashton, M. C., \& Lee, K. (2012). Profiling the "proenvironmental individual”: A personality perspective. Journal of personality, 80(1), 81-111. doi:10.1111/j.1467-6494.2011.00721.x.

McCrae, R. R., \& Costa, P.T. (1997). Personality trait structure as a human universal. American Psychologist, 52(5), 509-516. doi:10.1037/0003-066X.52.5.509.

McCrae, R. R., \& Costa, P. T., Jr. (2008). The Five-Factor Theory of personality. In O. P. John, R. W. Robins, \& L. A. Pervin (Eds.), Handbook of personality: Theory and research (3rd ed., pp. 159-180). New York, NY: Guilford Press.

MacKenzie, S.B., Podsakoff, P.M., \& Fetter R. (1993). The impact of organizational citizenship behavior on evaluations of salesperson performance. Journal of Marketing, 57(1),70-80.

Milfont, T. L., \& Sibley, C. G. (2012). The big five personality traits and environmental engagement: Associations at the individual and societal level. Journal of Environmental Psychology, 32(2), 187-195.

Mount, M. K., \& Barrick, M. R. (1995). The Big Five personality dimensions: Implications for research and practice in human resources management. In K. M. Rowland \& G. Fen-is (Eds.), Research in personnel and human resources management (Vol. 13, pp. 153-200). Greenwich, CT: JAI Press.

Mount, M. K., Barrick, M. R., \& Ryan, A. M. (2003). Research themes for the future. In M. R. Barrick \& A. M. Ryan (Eds.), Personality and work: Reconsidering the role of personality in organizations (pp. 326-344). San Francisco: Jossey-Bass. 
Ones, D.S., \& Viswesvaran, C. (1997). Empirical and theoretical considerations in using conscientiousness measures in personnel selection. Paper presented at the 5th European Congress of Psychology, Dublin, Ireland.

Ones, D. S., Viswesvaran, C., \& Schmidt, F. L. (1993). Comprehensive meta-analysis of integrity test validities: Findings and implications for personnel selection and theories of job performance. Journal of Applied Psychology, 78(4), 679-703.

Organ, D. W., Podsakoff, P. M., \& MacKenzie, S. B. (2006). Organizational Citizenship Behavior: its Nature, Antecedents, and Consequences. Sage: Thousand Oaks, CA.

Organ, D. W., \& Ryan, K. (1995). A meta-analytic review of attitudinal and dispositional predictors of organizational citizenship behavior. Personnel Psychology, 48(4), 775-802. doi:10.1111/j.1744-6570.1995.tb01781.x.

Paillé P., \& Boiral O. (2013). Pro-environmental behavior at work: construct validity and determinants. Journal of Environmental Psychology, 36, 118-128.

Ramus, C. A. (2001). Organizing support for employees: Encouraging creative ideas for environmental sustainability. California Management Review, 43(3), 85-103.

Ramus, C. A., \& Killmer, A. B. (2007). Corporate greening through prosocial extrarole behaviours: A conceptual framework for employee motivation. Business Strategy and the Environment, 16(8), 554-570. doi:10.1002/bse.504.

Ramus, C. A., \& Steger, U. (2000). The roles of supervisory support behaviours and environmental policy in employee "ecoinitiatives" at leading-edge European companies. Academy of Management Journal, 43(4), 605-626.

Roccas, S., Sagiv, L., Schwartz, S. H., \& Knafo, A. (2002). The Big Five personality factors and personal values. Personality and Social Psychology Bulletin, 28, 789-801.

Rothmann, S. \& Coetzer, E.P. (2003). The big five personality dimensions and job performance. SA Journal of Industrial Psychology, 29(1), 68-74

Sackett, P.R. \& Wannek, J.E. (1996). New developments in the use of measures of honesty, integrity, conscientiousness, dependability, trustworthiness and reliability of personnel selection. Personnel Psychology, 49, 787-830.

Theyel, G. (2000). Management practices for environmental innovation and performance. International Journal of Operations \& Production Management, 20, 249-266. 